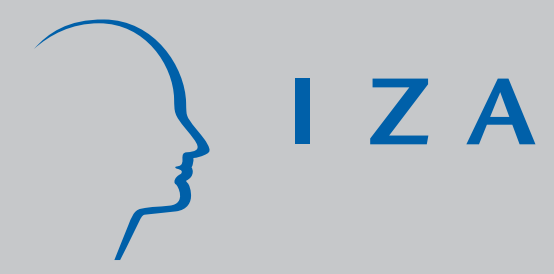

\author{
IZA DP No. 151 \\ Gender, Salary and Promotion \\ in the Academic Profession
}

Melanie Ward

May 2000 


\title{
Gender, Salary and Promotion in the Academic Profession
}

\author{
Melanie Ward \\ IZA, Bonn, Germany \\ Discussion Paper No. 151 \\ May 2000 \\ IZA \\ P.O. Box 7240 \\ D-53072 Bonn \\ Germany \\ Tel.: +49-228-3894-0 \\ Fax: +49-228-3894-210 \\ Email: iza@iza.org
}

This Discussion Paper is issued within the framework of IZA's research area The Future of Work. Any opinions expressed here are those of the author(s) and not those of the institute. Research disseminated by IZA may include views on policy, but the institute itself takes no institutional policy positions.

The Institute for the Study of Labor (IZA) in Bonn is a local and virtual international research center and a place of communication between science, politics and business. IZA is an independent, nonprofit limited liability company (Gesellschaft mit beschränkter Haftung) supported by the Deutsche Post AG. The center is associated with the University of Bonn and offers a stimulating research environment through its research networks, research support, and visitors and doctoral programs. IZA engages in (i) original and internationally competitive research in all fields of labor economics, (ii) development of policy concepts, and (iii) dissemination of research results and concepts to the interested public. The current research program deals with (1) mobility and flexibility of labor markets, (2) internationalization of labor markets and European integration, (3) the welfare state and labor markets, (4) labor markets in transition, (5) the future of work, (6) project evaluation and (7) general labor economics.

IZA Discussion Papers often represent preliminary work and are circulated to encourage discussion. Citation of such a paper should account for its provisional character. 
IZA Discussion Paper No. 151

May 2000

\section{ABSTRACT \\ Gender, Salary and Promotion in the Academic Profession*}

This paper examines the hypothesis that the gender salary gap observed in the academic labour market is predominantly explained by the differing average characteristics of male and female academics and barriers to female promotion. Preliminary analysis reveals that the crowding of women into the lower rungs of academia is a strong determinant of their lower average salary. This effect should be transitory as young women, now entering the profession, move up its ranks. We construct a rank attainment model and investigate the current and predicted distribution of females across ranks. Significant evidence of barriers to female promotion is revealed.

JEL Classification: J44, J70

Keywords: Academic profession, gender discrimination, promotion, salary

Melanie Ward

IZA

P.O. Box 7240

D-53072 Bonn

Germany

Tel.: +492283894306

Fax: +492283894210

Email: ward@iza.org

\footnotetext{
* The background research to this paper was completed during the course of my PhD at Aberdeen University, Scotland. I gratefully acknowledge funding provided by the Scottish Economic Society and European Commission (grant SOE2-CT97-3052) and helpful comments from Thomas Bauer, Peter J. Sloane, loannis Theodossiou and seminar participants at the CEPR/TSER workshop, 'Labour Demand, Education and the Dynamics of Social Exclusion', Bar-llan University, 1999, the European Economic Association Annual Congress, Santiago de Compostela 1999 and the European Association of Labour Economists Annual Conference, Regensburg 1999.
} 


\section{Introduction}

Conclusions from the Bett (1999) report, recently confirmed by the Association of University Teachers (1999), suggest the underpayment of women in relation to their male colleagues at every grade of the academic profession. Statistics from the Higher Education Statistics Agency suggest that female staff are concentrated on the lower rungs of fulltime academic staff, making up around $35 \%$ of researchers, but only $8 \%$ of professors (HESA 1996). Little is known, however, about the average human capital characteristics of male and female academics, which might help to explain some of the rank distribution and raw salary differentials observed within the profession. The lack of appropriate data in the UK is a particular problem. National statistics, collected by the Universities Statistical Record and later by the Higher Educational Statistics Agency (HESA), contain only very limited summary information. The census of academic salaries collected data on gender, age, date of recruitment, rank, faculty and salary, but ceased in 1993.

This paper examines the possibility that the gender rank distribution and salary gap observed in the academic labour market are predominantly explained by two factors. First, the differing average characteristics of male and female academics, and second, barriers to female promotion. We use a unique and detailed cross-sectional dataset collected from the academics of five Scottish universities, which includes detailed information on individual productivity, to provide some of the first economics literature looking at academic pay and promotion in Britain. Such an establishment level approach gives us a very detailed view of a labour force, but with some loss of generality.

Our approach initially follows that of Oaxaca (1973), widely applied in the consideration of gender salary differentials in the U.K labour market (see for example, Greenhalgh 1980, Dolton and Makepeace 1985, Zabalza and Arrufat 1985, Joshi and Newell 1986, Miller 1987 and Wright and Ermisch 1991). These studies identify a gender difference in salary which cannot be fully accounted for by differences in the quantity of human capital endowments. Instead, a proportion of the observed gender difference in salary is assigned to differences in rewards to male and female characteristics and can be thought of as the upper bound of discrimination. The use of this model 
here gives us a feel for some of the most important issues at work in the explanation of the gender salary gap in academia. We find significant evidence for a positive reward to mobility and publication, but to teaching to a lesser extent. Five factors dominate the explanation for the gender salary gap - age, working fulltime, faculty, rank and time out of the labour market. In total, $60 \%$ of the gender salary gap can be explained by these factors alone, thus the reliance of a gender discrimination argument based solely on raw differentials is misleading. Rank alone, however, explains $32 \%$ of the justified gender salary differential. The limited advancement of women in Scottish universities is suggested as the main determinant of their lower average salary.

The second stage of analysis uses a model along the lines of Jones and Makepeace (1996) to examine further the issue of barriers to female promotion. The model, which considers the contribution of inter and intra-rank distribution to the explanation of the gender salary gap, is adapted from Brown, Moon and Zoloth (1980) who study occupational distribution. As rank is more narrowly defined, the inter-rank contribution to the gender salary gap decreases and within narrow job categories, empirical evidence suggests no male-female differential. Much of the malefemale differential may therefore exist because men and women are assigned to different jobs (Lazear and Rosen 1990), or more specifically, women may be less likely to be found in higher paying jobs.

This argument is particularly interesting in the case of the academic profession, regulated as it is by a set framework of nationally agreed pay scales and appointment procedures, at least below professorial grades. The automatic progression of academics up the steps of a grade entails relatively small salary increments and offers limited capacity for gender differences in salary to open up. Job changes through promotion to a higher grade will usually result in more substantial changes in status and salary. The existence of any form of barriers to female promotion will therefore contribute strongly to any gender salary gap in academia. We construct a rank attainment model to investigate the determinants of academic promotion, separately for men and women, and apply the Brown, Moon and Zoloth (1980) model to simulate the female rank distribution that 
would hold if females faced similar entry (or promotion) requirements to higher grades as men. We further decompose the gender salary differential to allow for the explicit consideration of promotion barriers. In this second stage of analysis we find that the method by which academics are distributed across rank, that is the differential promotion rate of men and women, explains a significant proportion of gender differences in rank and explains a large part of gender differences in salary.

The plan of the paper is as follows. Section 2 outlines the main characteristics of the dataset used in this paper. Section 3 introduces the traditional and extended model for the study of gender salary differentials. Section 4 presents analysis using the traditional model of salary decomposition. Section 5 considers a model of rank attainment investigating the determinants of promotion in academia. Section 6 re-analyses the decomposition of the gender salary gap with particular interest in barriers to female promotion. Section 7 concludes.

\section{The Data}

The data used in this paper consist of a unique cross-section of 900 academics working in five Scottish Universities: Aberdeen, Dundee, Glasgow, Heriot-Watt and St. Andrews, in 1995/6. Data was collected through the use of a postal questionnaire and the careful designing of questions, making it possible to control for many more factors than with pre-collected data. The average response rate achieved was $30 \%$, reasonably high for this type of study ${ }^{1}$. The dataset encompasses detailed information on the personal background, education working history, productivity and job satisfaction of academics, where academic staff is taken to include professors, readers and senior lecturers, lecturers and research assistants. Excluding individuals for whom no salary data is available reduces our sample to just over 750 full and part time academics.

The majority of the women in the dataset are young women, three quarters of female academics in the five universities studied are under the age of forty. Correspondingly, women also have lower average experience in the academic labour market (the male mean is 12 years compared

\footnotetext{
${ }^{1}$ Data were weighted for non-response at a faculty level by sex allowing for non-response at the level of rank by sex.
} 
with the female mean of 5 years) and have on average published less (male mean: 32.38 referred publications, female mean: 7.79). Women in the Scottish academic profession, as in British academia as a whole, therefore differ substantially in their average characteristics to men. The majority of these women are also predominantly found in the lower rungs of an academic career, in the position of research assistant. This distribution may reflect historical influences on the relative ease of entry into academia for female staff in relation to male, in a very male dominated profession. Alternatively it may represent the failure of women to secure promotion to higher grades and early female exit from the profession as short term contracts, prevalent in the lower grades, terminate. One might expect female academics to have stronger long term work commitments than women in other labour markets, however, - partly due to the large investments in human capital, and partly to the fact that flexibility of academic career is more likely to allow a woman to combine a career with domestic and family responsibilities. These characteristics should enhance our ability to quantify gender differences. Summary statistics for the sample used in this analysis are presented in the appendix. For a more detailed description of the dataset please refer to Ward (1999).

The overwhelming advantage of this dataset is its uniqueness and detail. It allows us to undertake the first detailed analysis of salary and promotion within the academic profession. Its comparative disadvantage is it's cross sectional nature. We are only able to analyse a snap-shot of the academic profession at one point in time without the ability to correct for selection in and out of the profession. This restriction is an important caveat to the analysis that follows. Nevertheless the analysis of the cross sectional picture introduces some interesting propositions, to be challenged by future research.

\section{The Model}

The most widely used, and now standard, approach for the measurement of gender salary differences has been the direct regression approach of Oaxaca (1973) and Blinder (1973). This 
model determines wage as a function of personal characteristics and variables thought to be related to an individual's productivity. Two separate human capital regressions of earnings against individual characteristics are run, one for males and one for female workers, such as

$$
\begin{aligned}
& \operatorname{In}\left(W_{m}\right)=C_{m}+\left(X_{m}\right) m+e_{m} \\
& \operatorname{In}\left(W_{f}\right)=C_{f}+\left(X_{f}\right) f+e_{f}
\end{aligned}
$$

Where: $\operatorname{In}\left(W_{i}\right)=$ The log of pay where $i=m$ or $f$ (male or female).

$C_{i}=$ a constant term.

$X_{i}=$ the vector of male or female characteristics.

$m$ and $f=$ the respective coefficients on these characteristics.

$e_{i}=$ the error term.

The gender pay differential can then be calculated as:

$$
\operatorname{In}\left(\bar{W}_{m}\right)-\operatorname{In}\left(\bar{W}_{f}\right)=\left(\left(C_{m}-C_{f}\right)+\left(\bar{X}_{f}\right)(m-f)+\left(\bar{X}_{m}-\bar{X}_{f}\right) m\right)
$$

or

$$
\operatorname{In}\left(\bar{W}_{m}\right)-\operatorname{In}\left(\bar{W}_{f}\right)=\left(\left(C_{m}-C_{f}\right)+\left(\bar{X}_{m}\right)(m-f)+\left(\bar{X}_{m}-\bar{X}_{f}\right) f\right)
$$

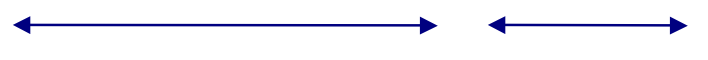

Where $\left(\bar{W}_{i}\right)=$ mean wages for $i=m$ or $f$ (males or females).

$\left(\bar{X}_{i}\right)=$ mean characteristics for $i=m$ or $f$ (males or females).

$\left(C_{i}\right)=$ constant terms from the $i=m$ or $f$ (male or female) earnings regressions.

$m$ and $f=$ male and female coefficients from the earnings regressions. 
Any differential in average pay between men and women therefore arises from firstly, A, the difference in rewards to male and female characteristics $(m-f)$ in the labour market, including the difference in constant terms $\left(C_{m}-C_{f}\right)$, and secondly, B, the difference in the quantity of these endowments held by men and women $\left(X_{m}-X_{f}\right)$. B can therefore be considered the non discriminatory or explained pay differential, or alternatively 'justified' discrimination. A can be thought of as the unjustified pay differential and provides the upper bound estimate of discrimination.

The standard Oaxaca-Binder decomposition presented in equation 4 however takes no account of gender differences in rank distribution. Whether an individual's rank is a function of supply conditions or the result of discrimination, the crowding of women into the lower rungs of academia that we observe in the dataset should not be treated exogenously. By including information concerning the actual and a predicted distribution of men and women across rank it is possible, adapting the approach by Brown, Moon and Zoloth (1980) to model the effect of rank distribution explicitly and further decompose the total earnings differential and write it as ${ }^{2}$ :

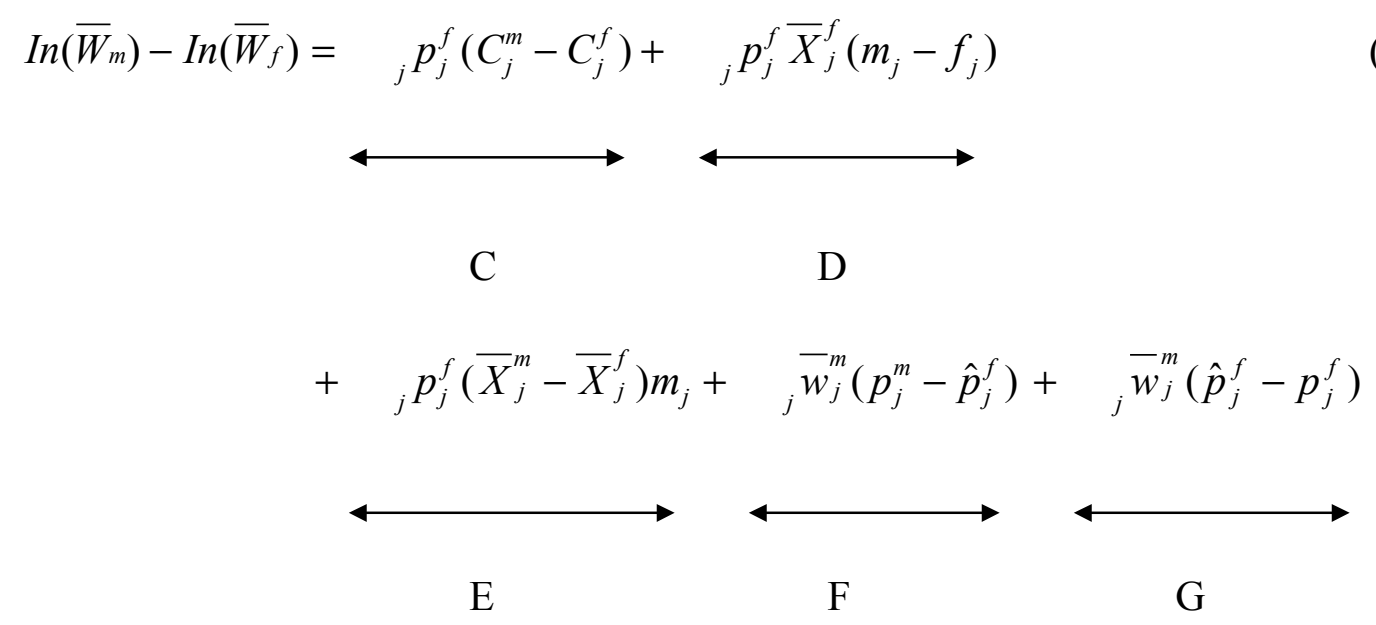

Mean characteristics $\left(\bar{X}_{j}\right)$, mean wages $\left(\bar{w}_{j}\right)$, constant terms $\left(C_{j}\right)$ and coefficients $m_{j}$ and $f_{j}$ are now given for the $j$ th rank. Proportions of men and women in the $j$ th rank are given by

\footnotetext{
${ }^{2}$ See Brown, Moon and Zoloth (1980) for the derivation of this equation.
} 
$p_{j}^{m}$ and $p_{j}^{f}$ respectively. $\hat{p}_{j}^{f}$ is a measure of the proportion of women in the sample who would be in rank $j$ if women faced the same promotion opportunity and therefore rank structure as men. An estimate of $\hat{p}_{j}^{f}$ is obtained by the construction of the rank attainment model for men and women discussed in section 5. Such analysis should tell us more about the underlying labour market processes involved in rank distribution.

Thus $\mathrm{D}$ and $\mathrm{E}$ from equation 5 can be interpreted as comparable to $\mathrm{A}$ and $\mathrm{B}$, respectively, from equation 4, while holding the distribution of women across rank constant. F represents the portion of the gender differential attributable to differences in the structure of rank between men and women and $\mathrm{G}$ the portion due to differences in qualifications for that rank. $\mathrm{C}$ and $\mathrm{D}$ therefore capture unjustified differences and E justified differences in within, or intra, rank gender wage differences. $\mathrm{F}$ and $\mathrm{G}$ represent the justified and unjustified portions, respectively, of between or inter rank gender wage differences.

\section{Model of salary determination}

Variables for inclusion in the salary determination model (equations 1 and 2) include those relating to an individual's personal characteristics (gender, age, family status, marital status), an individual's job characteristics (tenure, full time work), working and educational history, and productivity (publications, administrative duty, offices held and teaching performance). Variables relating to productivity can be argued to be an important determinant of earnings in an academic environment dominated by periodic teaching and research assessment, although this output effect may be weakened by automatic salary progression along a scale. There are no readily available measures of research and teaching productivity suggested in previous research (for a discussion see Hare and Wyatt 1988) and much of the US literature on the academic labour market does not include it at all. Here we use a yearly publication rate and most recent student assessment for each individual. The 
latter is an imperfect measure since students might not be entirely impartial in their teaching appraisal.

Where age and work experience are statistically separable, the level and shape of the earnings function is mainly a function of experience rather than age (Mincer 1994). The academic profession, however, with its fixed framework of financial reward requires a somewhat different specification. The relationship between age and salary is intensified with automatic progression along formal salary scales. Salary rising annually along a fixed salary scale means that years of experience, age and tenure are no longer so statistically separable. We must also be aware of a cohort effect in the academic profession ${ }^{3}$ and the effects of mobility on academic salary. Tenure and its square are therefore inserted into the earnings function to catch the effect of university specific investment and the mobility of academic staff and a dummy variable for academics over the age of 36 attempts to capture the cohort effect within the profession. A variable measuring the total length of time away from work is included to take account of inactivity due to for example child care. Dummy variables relating to number of previous positions, educational qualification and quality of educational institutions attended capture the effects of previous education and labour market experience.

Finally, dummy variables for faculty, university and rank are included in analysis to catch any differences in salary determination attributable to subject group, university and seniority. Due to argument over the exogeneity of rank, regressions are run both including and excluding this group of dummy variables.

Table 1 presents the results of ordinary least squares regression analysis ${ }^{4}$ of the log of salary on a series of explanatory variables. From the first column we see that in a pooled sample the gender variable is significant and positive. Male academics experience a $8.6 \%$ salary advantage

\footnotetext{
${ }^{3}$ The older academics in the dataset will experience a very different profession today to the one that they entered. Many will have observed the profession become more competitive with the onset of the research assessment exercises, and the increase in short term contracts. As a consequence of this, the older academics in the dataset hold less in the way of formal qualifications than those younger.

${ }^{4}$ Following tests for heteroskedasticity, all reported results show t-ratios derived from heteroscedastic-consistent standard errors using White's (1980) procedure. Normality tests could not reject the null hypothesis that the errors of the equation are independently and normally distributed.
} 
over female academics, not accounting for rank. Including dummy variables for rank (column 2) reduces this differential to just over $4 \%$ which is no longer significant. This finding is suggestive of the importance of rank in the explanation of the gender salary differential. McNabb and Wass (1995) find a similar effect for academic staff in old established UK universities over the years 1992, 1985 and 1975.

Touching briefly on other important results within this regression, we find a huge premium of $65-70 \%$ is associated with being a full-time as opposed to part-time academic. This suggests a limited role for parents who wish to combine family and career through part time work as in other labour markets. Rank is the second most important influence on an academic's salary. Professors earn $43 \%$ more, readers and senior lecturers $29 \%$ more and lecturers $9 \%$ more than the excluded category researchers. Results also reveal a concave tenure profile for academics, as in other labour markets, although the positive effect of age dominates.

Productivity variables such as the number of books published, an individual's publication rate, the number of offices held, administrative responsibility and teaching ability are significantly rewarded, over half of this effect is accounted for by the seniority of staff. Dropping productivity variables from regression analysis increases the dummy coefficient on gender from .086 to .105. Twenty two percent of an academic's salary is therefore dependent on an individuals' productivity. This compares with Barbezat's (1991) 25\% estimate for US academics in a system more reliant on individual performance in the absence of a formal salary structure.

Individuals who are mobile incur a positive salary premium (number of previous positions is positive and significant), as do individuals who completed their $\mathrm{PhD}$ at either Oxford or Cambridge, indicating reward to individual's ability. Academics in the universities of Aberdeen, Dundee, Heriot-watt and St.Andrews all experience a significant salary advantage over the comparator university Glasgow. This is an interesting finding, given that salaries are set on a nationally agreed pay scale and reveals flexibility in interpretation of salary grades by awarding universities. 
We should also comment on the relatively large constant term found in all reported regressions for academic salary. Previous studies of the UK academic labour market by Baimbridge and Simpson (1996), and McNabb and Wass (1995) have also found very large constant terms in regression analysis. It is most likely that the large constant term is symptomatic of a formal salary scale where progression up a point on a salary scale occurs annually, with a certain degree of automation.

Regression analysis undertaken separately for men and women is presented in columns 3 and 4 of table 1 excluding dummy variables for rank and columns 5 and 6 including them. Rank and full-time work have a strong effect on the annual salary of both male and female academics although, in contrast to evidence from the general UK labour market (Booth, Francesconi and Frank, 1988) the reward to promotion is substantially greater for women than men, shown by their larger coefficients on the dummy variables for rank. This implies that female academics are either less well paid than men in the rank below on promotion or that they were given more substantial pay increases on promotion than men. It could also be that more substantial increases are given when moves are made from temporary (research assistant) jobs to lectureships. Alternatively one might suggest a discrimination explanation for this finding, that is the later promotion of women in relation to their male counterparts.

Tables 2 presents the decomposition of the gender salary gap excluding and then including dummy variables for rank. The aggregate gender salary differential for academic staff is found to be 0.28 or around $30 \%$. This is double the $16 \%$ gap quoted by the AUT for 1990 and the $15 \%$ differential found by McNabb and Wass using 1992 data and reflects the inclusion of research assistants in our analysis. If we exclude these individuals from the dataset the differential falls to 0.18 , or $19 \%$. We find that excluding rank, over one quarter of the gender differential remains even after controlling for measured characteristics and represents the upper bound of discrimination. When rank is included, this unexplained proportion is reduced to $14 \%$ of the salary differential, substantially lower than estimates in other labour markets and partly reflecting the detail of 
variables included in analysis. Considering the individual contributions of each of the explanatory variables reveals that rank alone explains $27 \%$ of the total gender salary differential. This preliminary analysis therefore suggests the limited advancement of women in Scottish universities as the main determinant of their lower average salary.

\section{Model of rank attainment}

The theory of human capital also provides the basis for the investigation of the determinants of promotion within the academic profession, the first step in our calculation of equation 5. Two alternative explanations may be hypothesised for the observed gender difference in rank distribution of academics based on demand and supply orientated models. Under the demand or discrimination approach, gender segregation is the result of employers' discrimination against women in their promotion practices. Higher ranks become male dominated due to the faster promotion of men. Women are crowded into lower level grades, resulting in a reduction of their earnings in the lower paying sector. Under the supply explanation, an individual's rank is a consequence of their human capital investment prior to the promotion point. Benefits and costs of particular grades therefore vary between individuals depending on a variety of factors including individual skills, tastes, preferences and access to training. Theory predicts that if men and women are alike in all of these factors, their distribution across ranks will also be alike. Jones and Makepeace (1996) provide some of the first empirical findings on rank for the UK labour market. Using personnel data from a large British financial institution, they find some evidence to suggest that women have to meet more stringent criteria than men in order to be promoted, but that much of the difference between men and women's rank attainment is due to their attributes. Their analysis suggests that the gender differential in barriers to advancement might be greatest at lower rungs of the job ladder and that men and women receive more equal treatment once senior grades have been reached.

We estimate a rank attainment model where an individual's rank is a function both of an employee's wish to be promoted (a function of attitudes and family circumstances) and of an 
employer's wish to promote that individual (a function of human capital variables such as education and experience). The conditional probability that individual $i$ is observed in rank $j$ can be written as:

$$
P_{i j} / X_{i}=f\left(X_{i}\right)
$$

Where $X_{i}$ is a vector of our personal and labour market characteristics for individual $i$. Given the ordinal nature of rank we estimate this relationship using an ordered probit model. The conditional probability can therefore be re-written as:

$$
\hat{P}_{i j}=\Phi\left(c \hat{u} t_{j}-\hat{a} X_{i}\right)-\Phi\left(c \hat{u} t_{j-1}-\hat{a} X_{i}\right)
$$

Where $\Phi$ represents the standard normal cumulative density function, $\hat{a}$ the estimated coefficients and the $c \hat{u} t$ 's are estimated separation points. $J$ takes the value of 1 for researchers, 2 for lecturers and 3 for senior lecturers and professors ${ }^{5}$. Independent variables for inclusion in $X_{i}$ are classified under the headings of preferences or taste variables, proxied by individual characteristics (gender, family and marital status), worker characteristics (including job and educational history and individual productivity) and university characteristics, which include job characteristics (size of department, sex mix of department and working fulltime) and dummy variables for faculty and institution.

The results of ordered probit analysis of the determinants of rank for the pooled sample and for men and women separately are presented in table $3^{6}$. The positive significance of the coefficient on male in the first column implies a significant advantage for male academics in rank attainment. Holding worker and university characteristics constant, male academics are more likely to be found

\footnotetext{
${ }^{5}$ The very small number of women in the rank of professor means that the ranks of professor and senior lecturer have to be combined for the purpose of this analysis.

${ }^{6}$ Applying a likelihood ratio test to column 1 (restricted) and columns 2 and 3 (unrestricted) we can reject the null hypothesis that the restrictions are acceptable and accept the hypothesis that men and women have different equations.
} 
in the higher grades of the academic profession. It is tempting to explain this result on the basis of our demand or discrimination model - gender segregation across rank is the result of employers' discrimination against women in their promotion practices. More accurately however, this measure provides an upper bound of discriminatory behaviour by employers, since part of this male advantages may be capturing gender differences in individual preferences. The presence of children under the age of 16 has a positive impact on rank attainment for males, which may also be capturing an individual preference or motivation effect ${ }^{7}$.

Worker and university characteristics are also important in explaining the observed distribution of academics across grades. Working fulltime exhibits a strong influence on rank attainment for both men and women. Our results suggest that, particularly for women, working fulltime is very important in achieving high ranking status and may reflect the commitment to one's subject required for success in this profession. Experience is, as one would anticipate, positively related to rank, although we uncover no significant impact on rank attainment of career breaks or previous unemployment. An interesting result is the significantly negative effect of the percentage of female staff within a department on male rank attainment. Males face a lower promotion opportunity in female dominated areas.

A number of variables hint towards the importance of mobility to success in an academic career. Firstly observed individual mobility is important. We find that holding two consecutive jobs in the same university has a negative impact on rank attainment for men. Secondly academics may benefit from a mobile environment. The negative significance of the dummy variables on department size and St.Andrews could be interpreted as picking up this effect. The low mobility of academic staff in St. Andrews may create fewer opportunities for promotion. A large department on the other hand, with wider opportunity for joint research, money to back it and the greater mobility of staff may create greater the opportunity for promotion.

\footnotetext{
${ }^{7}$ In an alternative model, not presented here, we attempt to model individual preferences directly using information on factors academics reveal as particularly important in their current job. The size and significance of the gender dummy is unaffected within this alternative specification.
} 
One group of variables included in the model captures the effect of individual productivity on rank attainment. Of the various measures studied, publication rate and number of grants awarded increase the probability of promotion to a higher rank. We identify no such positive reward to administrative duty or teaching ability. An Oxbridge PhD and the number of discretionary awards received, included to capture an individual's past productivity successes, also increase the probability of an individual being found in the higher grades of the profession.

In the second stage of our investigation of rank attainment we simulate the female rank distribution that would hold if females faced similar entry (or promotion) requirements to higher grades as men. To do this, estimates from the male ordered probit model are taken and the female sample data substituted in. This produces for each female a vector of predicted probabilities of belonging to each rank, female characteristics being rewarded as if they were male. Summing over observations we simulate a female distribution where, holding human capital constant, females hold male preferences and face equivalent access to ranks. The results of this simulation are presented in table 4. The first three columns present the actual male and female distribution across ranks and the predicted female distribution. We see that the predicted and actual female distributions differ significantly. If women held the same preferences and experienced the same access to rank as men, a smaller proportion of women would work as researcher and a significantly larger proportion would achieve lecturer and particularly senior lecturer and professorial status. A large part of the difference in rank distribution between male and female academics can therefore be attributed to the way in which comparable males and females are allocated across rank, rather than the differences in male and female characteristics, although this distribution is a worst case scenario, since part of the difference between observed and simulated distribution may be due to unexplained differences in tastes.

Column 4 in table 4 simulates the distribution of males across rank that would hold if male allocation was determined by the female allocation equation, that is, holding human capital constant, if males held female preferences and faced the same access as females to rank. We find 
that under these circumstances a significantly higher proportion of men would hold the rank of researcher and lecturer and a significantly lower proportion would hold the rank senior lecturer or professor.

Thus, predicting either the male or female distribution across rank leads to the same conclusion. The method by which academics are distributed across rank, that is the differential promotion rate of men and women, is very important in the explanation of gender differences in rank. Policies which aim to alter the female distribution across rank will therefore need to consider equal opportunities policy at the promotion point.

\section{The effect of promotion barriers on the gender salary gap.}

The final stage of our investigation reanalyses the decomposition of the gender salary gap using equation 5 to analyse the impact of including rank distribution explicitly in estimates of the unexplained gender salary differential. The estimation of this model requires within-rank wage regressions and the predicted distribution of female academics across faculties obtained in the previous section. Equation 5 is interpreted with mean characteristics $\left(\bar{X}_{j}\right)$, mean wages $\left(\bar{w}_{j}\right)$, constant terms $\left(C_{j}\right)$ and coefficients $m_{j}$ and $f_{j}$ now given for the $j$ th rank with $J$ taking the value of 1 for the researchers, 2 for lecturers and 3 for senior lecturers and professors. Proportions of men and women in the $j$ th rank are given by $p_{j}^{m}$ and $p_{j}^{f}$ respectively. $\hat{p}_{j}^{f}$ measures the proportion of women in the sample who would be in rank $j$ if women faced the same rank structures as men.

Table 5 presents earnings functions estimated for men and women by each rank separately. The absence of female senior lecturers and professors under the age of 36 and in the faculty of engineering requires a simplified specification of the earnings equation in order to avoid over parameterisation. Miller (1987) has argued that imperfectly determined earnings equations for the female sample is not a major problem for the present analysis, so long as the male equation is 
accepted as the non discriminating norm. The specification therefore appears adequate for analysis with its focus on inter rank wage differentials.

Table 6 presents the results of decomposing the gender salary gap by allowing for both inter and intra rank effects. Comparison of the magnitude of these two components reveals that inter rank salary differentials are considerably larger than intra rank differences.

The justified and unjustified portions of the intra rank component echo the standard Oaxaca decomposition, but with the rank distribution of females held constant. The dominance of the unjustified portion suggests that differential reward to male and female characteristics are the predominant explanation for gender salary differentials within ranks. The negative sign of the justified component suggests that any difference in male and female average characteristics actually tends to boost female wages and reduce the gender salary gap, other things constant, although the magnitude of this effect is extremely small.

Examination of the inter rank effect reveals large positive justified and unjustified components. The justified component refers to the distribution of men and women across rank based on differences in male and female qualifications for each rank. The unjustified portion refers to the discrepancy between the observed female rank distribution and that which would arise if females were sorted into rank via the male ordered probit allocation equation (the simulated distribution). The dominance of the justified portion suggests that differences in male and female qualifications across rank are of central importance to the explanation of the aggregate gender salary differential. Approximately $60 \%$ of the total differential can be contributed to this effect. The historical male domination of the academic profession in the UK adds to this effect through the large proportion of young female academics in the dataset who have yet to gather experience and publication enough to reach the higher ranks. The crowding of female academics into the lower ranks of academia, providing that they stay within the profession, should therefore represent a transitory phenomenon. The unjustified proportion of the inter rank effect, however, contributes 
$12 \%$ to the total salary differential. This result suggests that the differential promotion rate of men to women explains up to one ninth of the aggregate wage differential in the academic profession.

In summary, the decomposition in table 8 therefore suggests that about $60 \%$ of the gender wage differential is justified, once accounting for the distribution of male and female academics. The remaining $40 \%$ can therefore be attributed to discrimination and female barriers to promotion and unmeasured gender differences in tastes. This is substantially larger than the $14 \%$ of the gender differential remaining when the decomposition of the gender salary gap is based on the conventional method of including dummy variables for rank and emphasises the importance of analysing rank distribution in the explanation of gender salary gaps within academia.

\section{Conclusion.}

This paper has examined the possibility that the gender salary gap observed in the academic labour market is predominantly explained by two factors. First, the differing average characteristics of male and female academics, and second, barriers to female promotion.

In our first step of analysis we find that rank, age, full-time work, time out of the labour market and faculty affiliation are revealed to be the largest contributors to the gender salary gap in the academic profession. The dominant contribution of rank to both the determination of academic salaries and the gender salary gap suggests vastly differential opportunities for promotion faced by men and women. The reward to realised promotion is substantially greater for women than men implying either that they are less well paid than men in the rank below on promotion or that they were given more substantial increases on promotion than men. It could also be that more substantial increases are given when moves are made from temporary (research assistant) jobs to lectureships.

Alternatively one might suggest a discrimination explanation for this finding, that is, the later promotion of women in relation to their male counterparts. In the second step of our analysis we construct a rank attainment model which reveals that, holding worker and university characteristics constant, male academics are more likely to be found in the higher grades of the 
academic profession. Simulating the distribution of female academics that would hold if females held the same preferences and experienced the same access to rank as men, we find that a smaller proportion of women would work in the rank of researcher than at present and a significantly larger proportion would achieve lecturer and particularly senior lecturer and professorial status. A large part of the difference in rank distribution between male and female academics can therefore be attributed to the way in which comparable males and females are allocated across rank or more explicitly, barriers to female promotion.

Analysis of the decomposition of the gender salary gap allowing for rank distributional effects reveals that differences in male and female qualification across rank is of central importance to the explanation of the aggregate gender salary differential. The majority of observed gender salary differentials will therefore disappear as the young women currently entering the UK academic profession acquire experience and reputation and proceed through the ranks. This process is firstly dependent on women staying within the profession - policy should actively encouragement this. The significant contribution of unequal treatment of male and female academic characteristics across ranks however also suggests the need for anti discrimination policy at promotion decision if this effect is to be fully realised. 
Table 1: OLS Human capital regression; dependent variable: log of salary.

\begin{tabular}{|c|c|c|c|c|c|c|}
\hline Variable & All & All & Females & Males & Females & Males \\
\hline \multicolumn{7}{|l|}{$\begin{array}{l}\text { INDIVIDUAL } \\
\text { CHARACTERISTICS }\end{array}$} \\
\hline MALE & $\begin{array}{l}.086^{* * * *} \\
(.027)\end{array}$ & $\begin{array}{l}.041 \\
(.025)\end{array}$ & & & & \\
\hline OVER 36 & $.283 * * *$ & $.180^{* * *}$ & $.256 * * *$ & $.307^{* * *}$ & $.142 * *$ & $.210^{* * *}$ \\
\hline CHILDREN $<16$ & $\begin{array}{l}.042 * \\
(.024)\end{array}$ & $\begin{array}{l}.028 \\
.028 \\
(.022)\end{array}$ & $\begin{array}{l}.008 \\
.055)\end{array}$ & $\begin{array}{l}(.000) \\
.021 \\
(028)\end{array}$ & $\begin{array}{l}.008) \\
-.007 \\
(052)\end{array}$ & $\begin{array}{l}.034) \\
.007 \\
(026)\end{array}$ \\
\hline MARRIED & $\begin{array}{l}-.038 \\
(.029)\end{array}$ & $\begin{array}{l}-.024 \\
(.027)\end{array}$ & $\begin{array}{l}-.051 \\
(.047)\end{array}$ & $\begin{array}{l}-.024 \\
(.033)\end{array}$ & $\begin{array}{l}-.048 \\
(.045)\end{array}$ & $\begin{array}{l}-.008 \\
(.030)\end{array}$ \\
\hline \multicolumn{7}{|l|}{ JOB CHARACTERISTICS } \\
\hline TENURE & $\begin{array}{l}.005 * * * \\
(.002)\end{array}$ & $\begin{array}{l}.002 \\
(.002)\end{array}$ & $\begin{array}{l}.010^{*} \\
(.006)\end{array}$ & $\begin{array}{l}.004^{*} \\
(.002)\end{array}$ & $\begin{array}{l}.010^{* *} \\
(.005)\end{array}$ & $\begin{array}{l}.001 \\
(.003)\end{array}$ \\
\hline TENURE $^{2}$ & $\begin{array}{l}-.00007 * * * \\
(.00002)\end{array}$ & $\begin{array}{l}-.00003 \\
(.00003)\end{array}$ & $\begin{array}{l}-.0001^{*} \\
(.00006)\end{array}$ & $\begin{array}{l}-.00006 \\
(.00004)\end{array}$ & $\begin{array}{l}-.00001 * * \\
(.00005)\end{array}$ & $\begin{array}{l}-.00004 \\
(.00006)\end{array}$ \\
\hline FULLTIME & $\begin{array}{l}.659 * * * \\
(.111)\end{array}$ & $\begin{array}{l}.611 * * * \\
(.110)\end{array}$ & $\begin{array}{l}.500 * * * \\
(.144)\end{array}$ & $\begin{array}{l}.847 * * * \\
(.161)\end{array}$ & $\begin{array}{l}.463 * * * \\
(.143)\end{array}$ & $\begin{array}{l}.794 * * * \\
(.164)\end{array}$ \\
\hline \multicolumn{7}{|l|}{ JOB \& EDUCATIONAL HISTORY } \\
\hline $1^{\mathrm{ST}}$ DEGREE FROM CURRENT UNI & $\begin{array}{l}.045 \\
(.030)\end{array}$ & $\begin{array}{l}.051^{*} \\
(.028)\end{array}$ & $\begin{array}{l}.004 \\
(.045)\end{array}$ & $\begin{array}{l}.062 * \\
(.037)\end{array}$ & $\begin{array}{l}.023 \\
(.043)\end{array}$ & $\begin{array}{l}.058^{*} \\
(.033\end{array}$ \\
\hline OXBRIDGE PHD & $\begin{array}{l}.084 * * * \\
(.023)\end{array}$ & $\begin{array}{l}.029 \\
(.023)\end{array}$ & $\begin{array}{l}.096 \\
(.065)\end{array}$ & $\begin{array}{l}.067 * * * \\
(.027)\end{array}$ & $\begin{array}{l}.068 \\
(.080)\end{array}$ & $\begin{array}{l}.017 \\
(.024)\end{array}$ \\
\hline TIME OUT OF THE L.MKT. & $\begin{array}{l}-.017 * * * \\
(.006)\end{array}$ & $\begin{array}{l}-.010^{*} \\
(.006)\end{array}$ & $\begin{array}{l}-.016^{*} \\
(.008)\end{array}$ & $\begin{array}{l}-.040 * * * \\
(.013)\end{array}$ & $\begin{array}{l}-.009 \\
(.008)\end{array}$ & $\begin{array}{l}-.022 * \\
(.012)\end{array}$ \\
\hline NUMBER OF PREVIOUS & $.022 * * *$ & $.021 * * *$ & $.026 * *$ & $.017 * * *$ & $.022 *$ & $.018^{* * *}$ \\
\hline \multicolumn{7}{|l|}{ PRODUCT } \\
\hline NUMBER OF BOOKS & $\begin{array}{l}.017 * * * \\
(.004)\end{array}$ & $\begin{array}{l}.005 \\
(.005)\end{array}$ & $\begin{array}{l}-.001 \\
(.015)\end{array}$ & $\begin{array}{l}.019 * * * \\
(.004)\end{array}$ & $\begin{array}{l}-.003 \\
(.013)\end{array}$ & $\begin{array}{l}.007 \\
(.005)\end{array}$ \\
\hline ANNUAL PUBLICATION RATE & $\begin{array}{l}.004 * * * \\
(.002)\end{array}$ & $\begin{array}{l}.002 * * \\
(.001)\end{array}$ & $\begin{array}{l}.038^{*} \\
(.020)\end{array}$ & $\begin{array}{l}.003 * * * \\
(.001)\end{array}$ & $\begin{array}{l}.020 \\
(.020)\end{array}$ & $\begin{array}{l}.002 * * \\
(.0007)\end{array}$ \\
\hline NUMBER OF OFFICES HELD & $\begin{array}{l}.012^{* * *} \\
(.004)\end{array}$ & $\begin{array}{l}.004 \\
(.003)\end{array}$ & $\begin{array}{l}.017 \\
(.012)\end{array}$ & $\begin{array}{l}.013^{* * *} \\
(.004)\end{array}$ & $\begin{array}{l}.003 \\
(.009)\end{array}$ & $\begin{array}{l}.007 * * \\
(.003)\end{array}$ \\
\hline ADMINISTRATIVE DUTY & $\begin{array}{l}.216^{* * *} \\
(.040)\end{array}$ & $\begin{array}{l}.142 * * * \\
(.042)\end{array}$ & $\begin{array}{l}.321 * * * \\
(.119)\end{array}$ & $\begin{array}{l}.176^{* * *} \\
(.038)\end{array}$ & $\begin{array}{l}.094 \\
(.153)\end{array}$ & $\begin{array}{l}.118^{* * *} \\
(.042)\end{array}$ \\
\hline $\begin{array}{l}\text { HIGH TEACHING ABILITY } \\
\text { FACULTY }\end{array}$ & $\begin{array}{l}.068^{* *} \\
(.032)\end{array}$ & $\begin{array}{l}.059^{*} \\
(.031)\end{array}$ & $\begin{array}{l}.145^{* *} \\
(.070)\end{array}$ & $\begin{array}{l}.024 \\
(.027)\end{array}$ & $\begin{array}{l}.125^{*} \\
(.064)\end{array}$ & $\begin{array}{l}.017 \\
(.024)\end{array}$ \\
\hline ENGINEERING & $\begin{array}{l}.079^{*} \\
(.045)\end{array}$ & $\begin{array}{l}.060 \\
(.041)\end{array}$ & $\begin{array}{l}.091 \\
(.079)\end{array}$ & $\begin{array}{l}.068 \\
(.044)\end{array}$ & $\begin{array}{l}.095 \\
(.081)\end{array}$ & $\begin{array}{l}.039 \\
(.041)\end{array}$ \\
\hline MEDICINE & $\begin{array}{l}.231^{* * *} \\
(.034)\end{array}$ & $\begin{array}{l}.206^{* * * *} \\
(.034)\end{array}$ & $\begin{array}{l}.178^{* * *} \\
(.058)\end{array}$ & $\begin{array}{l}.262 * * * \\
(.048)\end{array}$ & $\begin{array}{l}.215^{* * *} \\
(.061)\end{array}$ & $\begin{array}{l}.216^{* * *} \\
(.046)\end{array}$ \\
\hline SCIENCE & $\begin{array}{l}.085^{* *} \\
(.037)\end{array}$ & $\begin{array}{l}.075^{* *} \\
(.035)\end{array}$ & $\begin{array}{l}.138 \\
(.100)\end{array}$ & $\begin{array}{l}.060^{* *} \\
(.030)\end{array}$ & $\begin{array}{l}.180^{*} \\
(.105)\end{array}$ & $\begin{array}{l}.042 \\
(.028)\end{array}$ \\
\hline SOCIAL SCIENCE & $\begin{array}{l}.114^{* * * *} \\
(.033)\end{array}$ & $\begin{array}{l}.083 * * * \\
(.031)\end{array}$ & $\begin{array}{l}.156^{* * *} \\
(.059)\end{array}$ & $\begin{array}{l}.091 * * \\
(.044)\end{array}$ & $\begin{array}{l}.157^{* * *} \\
(.056)\end{array}$ & $\begin{array}{l}.055 \\
(.042)\end{array}$ \\
\hline UNIVERSITY & & & & & & \\
\hline ABERDEEN & $\begin{array}{l}.083^{* * *} \\
(.031)\end{array}$ & $\begin{array}{l}.047^{*} \\
(.029)\end{array}$ & $\begin{array}{l}.056 \\
(.067)\end{array}$ & $\begin{array}{l}.094 * * * \\
(.034)\end{array}$ & $\begin{array}{l}.037 \\
(.059)\end{array}$ & $\begin{array}{l}.054^{*} \\
(.032)\end{array}$ \\
\hline DUNDEE & $\begin{array}{l}.067 * * * \\
(.026)\end{array}$ & $\begin{array}{l}.039^{*} \\
(.023)\end{array}$ & $\begin{array}{l}.026 \\
(.031)\end{array}$ & $\begin{array}{l}.107 * * * \\
(.037)\end{array}$ & $\begin{array}{l}.016 \\
(.029)\end{array}$ & $\begin{array}{l}.066 * * \\
(.033)\end{array}$ \\
\hline HERIOT-WATT & $\begin{array}{l}.084 * * * \\
(.033)\end{array}$ & $\begin{array}{l}.057^{*} \\
(.031)\end{array}$ & $\begin{array}{l}.165^{*} \\
(.092)\end{array}$ & $\begin{array}{l}.109^{* * *} \\
(.035)\end{array}$ & $\begin{array}{l}.105 \\
(.093)\end{array}$ & $\begin{array}{l}.076^{* * *} \\
(.033)\end{array}$ \\
\hline ST. ANDREWS & $\begin{array}{l}.094 * * \\
(.042)\end{array}$ & $\begin{array}{l}.093 * * \\
(.041)\end{array}$ & $\begin{array}{l}.125 \\
(.111)\end{array}$ & $\begin{array}{l}.079 * \\
(.044)\end{array}$ & $\begin{array}{l}.161 \\
(.112)\end{array}$ & $\begin{array}{l}.063 \\
(.040)\end{array}$ \\
\hline $\begin{array}{l}\text { RANK } \\
\text { LECTURER }\end{array}$ & & $\begin{array}{l}.087^{* * *} \\
(.029)\end{array}$ & & & $\begin{array}{l}.100^{*} \\
(.057)\end{array}$ & $\begin{array}{l}.082 * \\
(.042)\end{array}$ \\
\hline SENIOR LECTURER / & & $.289^{* * *}$ & & & $.307 * * *$ & $.267 * * *$ \\
\hline READER & & $(.045)$ & & & $(.095)$ & $(.054)$ \\
\hline PROFESSOR & & $\begin{array}{l}.432 * * * \\
(.050)\end{array}$ & & & $\begin{array}{l}.682 * * * \\
(.133)\end{array}$ & $\begin{array}{l}.393 * * * \\
(.054)\end{array}$ \\
\hline CONSTANT & $\begin{array}{l}8.905 * * * \\
(.094)\end{array}$ & $\begin{array}{l}8.977 * * * \\
(.095)\end{array}$ & $\begin{array}{l}9.031 * * * \\
(.129)\end{array}$ & $\begin{array}{l}8.835 * * * \\
(.153)\end{array}$ & $\begin{array}{l}9.041 * * * \\
(.128)\end{array}$ & $\begin{array}{l}8.880^{* * *} \\
(.163)\end{array}$ \\
\hline No of obs. & 752 & 752 & 242 & 510 & 242 & 510 \\
\hline $\mathrm{R}$ squared & .617 & .678 & .532 & .637 & .601 & .701 \\
\hline $\mathrm{F}(.,)$. & $\mathrm{F}(24,727)$ & $\mathrm{F}(27,724)$ & $F(23,218)$ & $\mathrm{F}(23,486)$ & $\mathrm{F}(26,215)$ & $F(26,215)$ \\
\hline Prob $>$ F & $\begin{array}{l}57.78 \\
.000\end{array}$ & $\begin{array}{l}60.19 \\
.000\end{array}$ & $\begin{array}{l}16.72 \\
.000\end{array}$ & $\begin{array}{l}29.61 \\
.000\end{array}$ & $\begin{array}{l}16.81 \\
.000\end{array}$ & $\begin{array}{l}16.81 \\
.000\end{array}$ \\
\hline
\end{tabular}

$* * *$ indicates significance at $1 \%$ level, $* *$ indicates significance at $5 \%$ level, *indicates significance at $10 \%$ level

Reference groups: Arts faculty, University of Glasgow, Rank of Researcher. 
Table 2: Decomposition of the gender wage differential.

\begin{tabular}{|c|c|c|}
\hline Excluding rank & Observed wage differential & 0.28 \\
\hline & Justified & 0.20 \\
\hline & Unjustified & 0.08 \\
\hline \multirow[t]{10}{*}{ Including rank } & Observed wage differential & 0.28 \\
\hline & Justified & 0.24 \\
\hline & Over 36 & $16.85 \%$ \\
\hline & Fulltime & $11.62 \%$ \\
\hline & Medicine & $13.53 \%$ \\
\hline & Time out & $6.28 \%$ \\
\hline & Lecturer & $0.45 \%$ \\
\hline & Senior lecturer & $11.33 \%$ \\
\hline & Professor & $19.80 \%$ \\
\hline & Unjustified & 0.04 \\
\hline
\end{tabular}


Table 3: Ordered Probit regression; dependent variable: Rank.

\begin{tabular}{|c|c|c|c|}
\hline Variable & All & Females & Males \\
\hline $\begin{array}{l}\text { INDIVIDUAL CHARACTERISTICS } \\
\text { MALE }\end{array}$ & $\begin{array}{l}.530 * * * \\
(.131)\end{array}$ & & \\
\hline CHILDREN $<16$ & .348 & $\begin{array}{l}.142 \\
(.245)\end{array}$ & $\begin{array}{l}.513^{* * *} \\
(.150)\end{array}$ \\
\hline MARRIED & $\begin{array}{l}.072 \\
(.128)\end{array}$ & $\begin{array}{l}-.054 \\
(.248)\end{array}$ & $\begin{array}{l}.152 \\
(158)\end{array}$ \\
\hline JOB CHARACTERISTICS & & & \\
\hline FULLTIME & $\begin{array}{l}.844 * * * \\
(.227)\end{array}$ & $\begin{array}{l}1.073 * * * \\
(.365)\end{array}$ & $\begin{array}{l}.703 * * \\
(.325)\end{array}$ \\
\hline $\begin{array}{l}\text { PERCENTAGE OF FEMALE STAFF IN } \\
\text { DEPARTMENT }\end{array}$ & $\begin{array}{l}-.008^{* * *} \\
(.003)\end{array}$ & $\begin{array}{l}-.005 \\
(.005)\end{array}$ & $\begin{array}{l}-.595^{* * *} \\
(.185)\end{array}$ \\
\hline DEPARTMENT $<10$ & $\begin{array}{l}-.310^{*} \\
(.169)\end{array}$ & $\begin{array}{l}-.518 \\
(.353)\end{array}$ & $\begin{array}{l}-.333 \\
(.206)\end{array}$ \\
\hline DEPARTMENT 11-20 & $\begin{array}{l}-.277^{*} \\
(.148)\end{array}$ & $\begin{array}{l}-.322 \\
(.327)\end{array}$ & $\begin{array}{l}-.287 \\
(.177)\end{array}$ \\
\hline $\begin{array}{l}\text { DEPARTMENT 21-30 } \\
\text { JOB HISTORY }\end{array}$ & $\begin{array}{l}-.337 * * \\
(.157)\end{array}$ & $\begin{array}{l}-.207 \\
(.319)\end{array}$ & $\begin{array}{l}-.213 \\
(.190)\end{array}$ \\
\hline TIME OUT OF THE L.MKT. & $\begin{array}{l}-.034 \\
(.029)\end{array}$ & $\begin{array}{l}-.035 \\
(.037)\end{array}$ & $\begin{array}{l}-.072 \\
(.092)\end{array}$ \\
\hline EXPERIENCE & $\begin{array}{l}.143 * * * \\
(.022)\end{array}$ & $\begin{array}{l}.243 * * * \\
(.058)\end{array}$ & $\begin{array}{l}.096^{* * *} \\
(.026)\end{array}$ \\
\hline EXPERIENCE $^{2}$ & $\begin{array}{l}-.002 * * * \\
(001)\end{array}$ & $\begin{array}{l}-.004 * * \\
(.002)\end{array}$ & $\begin{array}{l}-.001 \\
(.001)\end{array}$ \\
\hline PREVIOUSLY UNEMPLOYED & $\begin{array}{l}.396^{* *} \\
(.183)\end{array}$ & $\begin{array}{l}.167 \\
(.317)\end{array}$ & $\begin{array}{l}.539 * * \\
(.242)\end{array}$ \\
\hline $\begin{array}{l}\text { HELD LAST JOB IN SAME UNIVERSITY } \\
\text { PRODUCT }\end{array}$ & $\begin{array}{l}-.479^{* * *} \\
(.154)\end{array}$ & $\begin{array}{l}-.388 \\
(.321)\end{array}$ & $\begin{array}{l}-.015 * * * \\
(.004)\end{array}$ \\
\hline NUMBER OF BOOKS & $\begin{array}{l}.042 \\
(.031)\end{array}$ & $\begin{array}{l}-.033 \\
(.083)\end{array}$ & $\begin{array}{l}.077^{* *} \\
(.036)\end{array}$ \\
\hline ANNUAL PUBLICATION RATE & $\begin{array}{l}.236^{* * *} \\
(.047)\end{array}$ & $\begin{array}{l}.401 * * * \\
(.120)\end{array}$ & $\begin{array}{l}.195 * * * \\
(.052)\end{array}$ \\
\hline HIGH TEACHING ABILITY & $\begin{array}{l}.124 \\
(.123)\end{array}$ & $\begin{array}{l}.223 \\
(.278)\end{array}$ & $\begin{array}{l}.127 \\
(.145)\end{array}$ \\
\hline NUMBER OF GRANTS RECEIVED & $\begin{array}{l}.025^{* * * *} \\
(.008)\end{array}$ & $\begin{array}{l}.007 \\
(.016)\end{array}$ & $\begin{array}{l}.034^{* * * *} \\
(.011)\end{array}$ \\
\hline NUMBER OF DISCRETIONARY AWARDS & $\begin{array}{l}.122^{* * *} \\
(.058)\end{array}$ & $\begin{array}{l}.301 * * * \\
(.127)\end{array}$ & $\begin{array}{l}.074 \\
(.068)\end{array}$ \\
\hline ADMINISTRATIVE DUTY & $\begin{array}{l}.036 \\
(.281)\end{array}$ & $\begin{array}{l}-.093 \\
(.711)\end{array}$ & $\begin{array}{l}-.068 \\
.308\end{array}$ \\
\hline PHD FROM CURRENT UNI & $\begin{array}{l}-.158 \\
(.140)\end{array}$ & $\begin{array}{l}-.718^{*} \\
(.390)\end{array}$ & $\begin{array}{l}.141 \\
(.164)\end{array}$ \\
\hline $\begin{array}{l}\text { OXBRIDGE PHD } \\
\text { FACULTY }\end{array}$ & $\begin{array}{l}.395^{* *} \\
(.189)\end{array}$ & $\begin{array}{l}.134 \\
(.518)\end{array}$ & $\begin{array}{l}.475^{* *} \\
(.207)\end{array}$ \\
\hline ARTS & $\begin{array}{l}.153 \\
(.187)\end{array}$ & $\begin{array}{l}.128 \\
(.340)\end{array}$ & $\begin{array}{l}.230 \\
(.236)\end{array}$ \\
\hline MEDICINE & $\begin{array}{l}-.385 * * * \\
(.170)\end{array}$ & $\begin{array}{l}-.902 * * * \\
.303\end{array}$ & $\begin{array}{l}.064 \\
(.235)\end{array}$ \\
\hline SCIENCE AND ENGINEERING & $\begin{array}{l}-.680 * * * \\
(.171)^{* * * *}\end{array}$ & $\begin{array}{l}-.978 * * * \\
(.350)\end{array}$ & $\begin{array}{l}-.618^{* * * *} \\
(.215)\end{array}$ \\
\hline
\end{tabular}




\begin{tabular}{|c|c|c|c|}
\hline \multicolumn{4}{|l|}{ UNIVERSITY } \\
\hline \multirow[t]{2}{*}{ ABERDEEN } & $.745 * * *$ & $.983 * * *$ & $.663 * * *$ \\
\hline & $(.162)$ & $(.327)$ & $(.192)$ \\
\hline \multirow[t]{2}{*}{ DUNDEE } & $.465 * * *$ & .195 & $.587 * * *$ \\
\hline & $(.138)$ & $(.248)$ & $(.184)$ \\
\hline \multirow[t]{2}{*}{ HERIOT-WATT } & $.543 * * *$ & $1.724 *$ & $.571 * * *$ \\
\hline & $(.221)$ & $(.989)$ & $(.229)$ \\
\hline \multirow[t]{2}{*}{ ST. ANDREWS } & $-.527 * * *$ & $-.941 * * *$ & -.236 \\
\hline & $(.163)$ & $(.399)$ & $(.192)$ \\
\hline \multirow[t]{2}{*}{ _CUT1 } & 2.360 & 2.697 & 1.618 \\
\hline & $(.383)$ & $(.720)$ & $(.484)$ \\
\hline \multirow[t]{2}{*}{ CUT2 } & 4.211 & 4.974 & 3.443 \\
\hline & $(.409)$ & $(.792)$ & $(.509)$ \\
\hline No of obs. & 752 & 242 & 510 \\
\hline \multirow[t]{2}{*}{ LR chi2 } & LR $\operatorname{chi} 2(28)=$ & LR $\operatorname{chi} 2(27)=$ & LR $\operatorname{chi} 2(27)=$ \\
\hline & 747.65 & 220.18 & 415.01 \\
\hline Prob > chi 2 & .000 & .000 & .000 \\
\hline Pseudo R2 & .453 & .484 & .401 \\
\hline
\end{tabular}

Table 4: Predicted and actual distribution of academics across rank.

\begin{tabular}{lllll}
\hline Rank & Actual male & Actual female & Predicted female & Predicted male \\
\hline Researchers & .19 & .53 & .43 & .27 \\
Lecturers & .35 & .34 & .40 & .36 \\
Lecturers and Professors & .46 & .13 & .17 & .38 \\
\hline
\end{tabular}


Table 5: OLS Human capital regression by rank; dependent variable: log of salary.

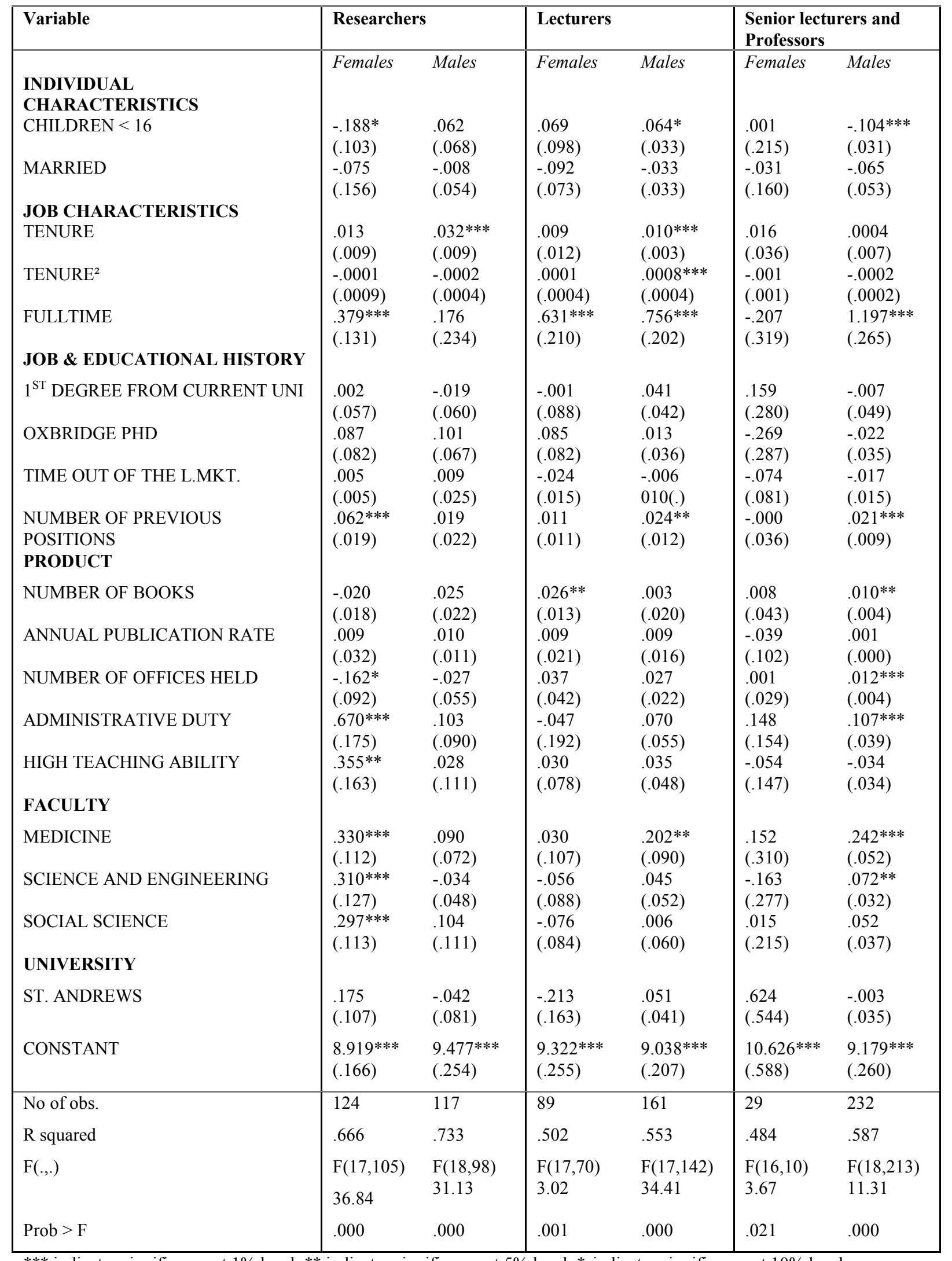

*** indicates significance at $1 \%$ level, ** indicates significance at $5 \%$ level, * indicates significance at $10 \%$ level Reference groups: engineering faculty, Universities of Glasgow, Heriot-Watt, Aberdeen, Dundee 
Table 6: Decomposition of gender wage differential specifying inter and intra rank effects.

\begin{tabular}{llc}
\hline Observed wage differential & & 0.28 \\
\hline Intra Rank effects & Justified & -0.008 \\
& Unjustified & 0.094 \\
Inter Rank effects & Justified & 0.161 \\
& Unjustified & 0.033 \\
\hline
\end{tabular}




\section{References.}

Association of University Teachers (AUT) (1992), Sex Discrimination in Universities: Report of an Academic Pay Audit carried out by the AUT Research Department, AUT, London.

Association of University Teachers AUT (1999), Pay gaps and Causal Jobs, An Analysis of the gender, pay and employment of UK academic staff, AUT Research, November 1999.

Baimbridge, M. and Simpson, C. (1996), Rewards to Academia: the remuneration of vice chancellors and Principals, Applied Economics, Vol. 28, pp.631-639.

Barbezat, D. A. (1991), Updating estimates of male-female salary differentials in the academic labor market, Economics Letters, Vol. 36, pp.191-95.

Becker, G. S. (1964), Human Capital: A Theoretical and Empirical Analysis with special reference to Education, National Bureau of Economic Research, Columbia University Press, New York.

Bett, M. (1999), Independent Review of Higher Education Pay and Conditions, report of a Committee chaired by Sir Michael Bett.

Blinder, A. (1973), Wage Discrimination: Reduced Form and Structural Estimates, Journal of Human Resources, Vol. 8, pp.36-55.

Booth, A., Francesconi, M. and Frank, J. (1988), Glass ceilings or Sticky Floors, CEPR Discussion Paper No 98/23 (1998).

Brown, R. S., Moon, M. and Zoloth, B. S. (1980), Incorporating Occupational Attainment in Studies of Male-Female Earnings Differentials, Journal of Human Resources, Vol. XV, pp.3-28.

Dolton, P. J. and Makepeace, G. (1985), The Statistical Measurement of Discrimination, Economics Letters, Vol. 18, pp.391-395.

Greenhalgh, C. (1980), Male-Female Differentials in Great Britain: Is Marriage an Equal Opportunity?, Economic Journal, Vol. 90, pp.751-775. 
Hare. P. and Wyatt, G. (1988), Modelling the determinants of research output in British universities, Research Policy, Vol. 17, pp.315-328.

Jones, D. R. and Makepeace, G. H. (1996), Equal Worth, Equal Opportunities: Pay and Promotion in an Internal Labour Market', The Economic Journal, Vol. 106, No 435, pp 401-9.

Joshi, H. E. and Newell, M. (1986), Pay Differences between Men and Women: Longitudinal Evidence from the 1946 Birth Cohort, Centre for Economic Policy Research, Discussion paper 156.

Lazear, E. P. and Rosen, S. (1990), Male-Female Wage Differentials in Job Ladders, Journal of Labor Economics, Vol. 8, pp.S106-S123.

McNabb, R. and Wass V. (1995), Gender Differences in British Academic Salaries and Promotion Probabilities, Preliminary Draft, Cardiff Business School.

Miller, P. W. (1987), The Wage Effect of The Occupational Segregation of Women in Britain, The Economic Journal, Vol. 97, pp.885-896.

Mincer, J. (1994), Human Capital: A Review.

Oaxaca, R. (1973), Male-Female Wage Differentials in Urban Labor Markets, International Economic Review, Vol. 14, 3, pp.693-709.

Ward, M. E. (1999), Your Everyday, Average Academic, IZA Discussion Paper No.63.

Ward, M. E. and Sloane, P. J. (2000), Non-Pecuniary Advantages Versus Pecuniary Disadvantages; Job Satisfaction Among Male and Female Academics in Scottish Universities, forthcoming in Scottish Journal of Political Economy, May Issue.

White, H. (1980), A heteroskedasticity-consistent covariance matrix estimator and a direct test for heteroskedasticity, Econometrica, Vol. 48, pp.817-830. 
Wright, R. E. and Ermisch, J. F. (1991), Gender Discrimination in the British Labour Market: A Re-Assessment, Economic Journal, Vol. 101, No. 406, pp.508 521.

Zabalza, A. and Arrufat, J. L. (1985), The extent of sex discrimination in Great Britain, in Women and Equal Pay: The effects of legislation on female wages and employment in Britain, (A. Zabalz and Z. Tzannatos, eds), pp.70-96, Cambridge University Press. 
Appendix Table 1: Variable List and Summary Statistics

\begin{tabular}{|c|c|c|c|c|c|}
\hline Variable & Definition & $\begin{array}{l}\text { Means } \\
\text { Females }\end{array}$ & Males & $\begin{array}{l}\text { Std. Dev. } \\
\text { Females }\end{array}$ & Males \\
\hline ABERDEEN & $\begin{array}{l}=1 \text { if respondent works in the university } \\
\text { of Aberdeen, }=0 \text { otherwise. }\end{array}$ & 0.126 & 0.186 & 0.332 & 0.389 \\
\hline $\begin{array}{l}\text { ADMINISTRATIVE } \\
\text { DUTY }\end{array}$ & $\begin{array}{l}=1 \text { if respondent holds administrative } \\
\text { duty, }=0 \text { otherwise. }\end{array}$ & 0.017 & 0.055 & 0.130 & 0.228 \\
\hline $\begin{array}{l}\text { ANNUAL } \\
\text { PUBLICATION RATE }\end{array}$ & $\begin{array}{l}\text { Respondent's publication rate (=number } \\
\text { of articles published/length of academic } \\
\text { work experience) }\end{array}$ & 0.843 & 1.912 & 1.003 & 6.224 \\
\hline ARTS & $\begin{array}{l}=1 \text { if respondent works within the faculty } \\
\text { of science, }=0 \text { otherwise. }\end{array}$ & 0.164 & 0.178 & 0.371 & 0.383 \\
\hline CHILDREN $<16$ & $\begin{array}{l}=1 \text { if respondent has children under the } \\
\text { age of } 16,=0 \text { otherwise. }\end{array}$ & 0.371 & 0.389 & 0.484 & 0.488 \\
\hline $1^{\text {st }}$ DEGREE FROM & $=1$ if respondent gained their first degree & & & & \\
\hline CURRENT UNI & $\begin{array}{l}\text { at the university of their current position, } \\
0 \text { otherwise. }\end{array}$ & 0.281 & 0.206 & 0.450 & 0.405 \\
\hline DEPARTMENT $>10$ & $\begin{array}{l}\text { Size of department variable } \\
=1 \text { if under } 10 \text { academic staff, }=0 \\
\text { otherwise. }\end{array}$ & .212 & .231 & .409 & .422 \\
\hline DEPARTMENT 11-20 & $\begin{array}{l}\text { Size of department variable } \\
=1 \text { if between } 1 \text { and } 20 \text { academic staff, }=0 \\
\text { otherwise. }\end{array}$ & .309 & .284 & .462 & .452 \\
\hline DEPARTMENT 21-30 & $\begin{array}{l}\text { Size of department variable } \\
=1 \text { if between } 21 \text { and } 30 \text { academic staff, } \\
=0 \text { otherwise. }\end{array}$ & .235 & .313 & .424 & .465 \\
\hline DUNDEE & $\begin{array}{l}=1 \text { if respondent works in the university } \\
\text { of Dundee, }=0 \text { otherwise. }\end{array}$ & 0.337 & 0.182 & 0.473 & 0.387 \\
\hline ENGINEERING & $\begin{array}{l}=1 \text { if respondent works within the faculty } \\
\text { of engineering, }=0 \text { otherwise. }\end{array}$ & 0.045 & 0.150 & 0.208 & 0.358 \\
\hline EXPERIENCE & $\begin{array}{l}\text { Length total labour market experience, } \\
\text { measured in years. }\end{array}$ & 11.998 & 20.260 & 8.428 & 11.093 \\
\hline EXPERIENCE $^{2}$ & Experience squared & 214.721 & 533.320 & 278.745 & 467.422 \\
\hline FULLTIME & $\begin{array}{l}=1 \text { if respondent works over } 30 \text { hours per } \\
\text { week, }=0 \text { otherwise. }\end{array}$ & 0.902 & 0.957 & 0.298 & 0.204 \\
\hline GLASGOW & $\begin{array}{l}=1 \text { if respondent works in the university } \\
\text { of Glasgow, }=0 \text { otherwise. }\end{array}$ & 0.337 & 0.357 & 0.474 & 0.479 \\
\hline $\begin{array}{l}\text { HELD LAST JOB IN } \\
\text { SAME UNIVERSITY }\end{array}$ & $\begin{array}{l}=1 \text { if respondent's last job was in the } \\
\text { university of their current position, }=0 \\
\text { otherwise. }\end{array}$ & 0.130 & 0.138 & 0.337 & 0.345 \\
\hline HERIOT-WATT & $\begin{array}{l}=1 \text { if respondent works in the university } \\
\text { of Heriot-Watt, }=0 \text { otherwise. }\end{array}$ & 0.018 & 0.101 & 0.132 & 0.301 \\
\hline $\begin{array}{l}\text { HIGH TEACHING } \\
\text { ABILITY }\end{array}$ & $\begin{array}{l}=1 \text { if respondent's self reported student } \\
\text { assessment was very good. }\end{array}$ & .244 & .208 & .429 & .407 \\
\hline LECTURER & $\begin{array}{l}=1 \text { if respondent is a lecturer, }=0 \\
\text { otherwise. }\end{array}$ & 0.320 & 0.353 & 0.467 & 0.478 \\
\hline MALE & $=1$ if male, $=0$ if female & & & & \\
\hline MARRIED & $=1$ if respondent is married, $=0$ otherwise. & .333 & .483 & .471 & .501 \\
\hline MEDICINE & $\begin{array}{l}=1 \text { if respondent works within the faculty } \\
\text { of medicine, }=0 \text { otherwise. }\end{array}$ & 0.453 & 0.205 & 0.499 & 0.404 \\
\hline NUMBER OF BOOKS & $\begin{array}{l}\text { The number of books published by a } \\
\text { respondent. }\end{array}$ & 0.392 & 1.443 & 1.250 & 2.848 \\
\hline $\begin{array}{l}\text { NUMBER OF } \\
\text { DISCRETIONARY } \\
\text { AWARDS }\end{array}$ & $\begin{array}{l}\text { Number of discretionary awards received } \\
\text { in total. }\end{array}$ & 0.304 & 0.645 & 0.822 & 1.032 \\
\hline NUMBER OF GRANTS & Number of grants received. & 2.589 & 6.636 & 6.383 & 8.681 \\
\hline $\begin{array}{l}\text { NUMBER OF OFFICES } \\
\text { HELD }\end{array}$ & Number of university offices held in total. & 0.456 & 1.359 & 1.366 & 3.642 \\
\hline
\end{tabular}




\begin{tabular}{|c|c|c|c|c|c|}
\hline $\begin{array}{l}\text { NUMBER OF } \\
\text { PREVIOUS } \\
\text { POSITIONS }\end{array}$ & Number of posts held over working life. & 3.629 & 3.402 & 2.422 & 1.874 \\
\hline OVER36 & $\begin{array}{l}=1 \text { if respondent is over the age of } 36,=0 \\
\text { otherwise. }\end{array}$ & 0.390 & 0.695 & 0.489 & 0.461 \\
\hline OXBRIDGE PHD & $\begin{array}{l}=1 \text { if respondent gained their Ph.D. at } \\
\text { Oxbridge, }=0 \text { otherwise. }\end{array}$ & 0.036 & 0.128 & 0.187 & 0.334 \\
\hline $\begin{array}{l}\text { PERCENAGE OF } \\
\text { FEMALE STAFF IN } \\
\text { DEPARTMENT }\end{array}$ & $\begin{array}{l}\text { Percentage of female academic staff in } \\
\text { respondent's department. }\end{array}$ & 32.544 & 19.413 & 24.236 & 17.771 \\
\hline $\begin{array}{l}\text { PHD FROM CURRENT } \\
\text { UNI }\end{array}$ & $\begin{array}{l}=1 \text { if respondent gained their } \mathrm{PhD} \text { at the } \\
\text { university of their current position, } 0 \\
\text { otherwise. }\end{array}$ & .191 & .218 & .394 & .414 \\
\hline $\begin{array}{l}\text { PREVIOUSLY } \\
\text { UNEMPLOYED }\end{array}$ & $\begin{array}{l}=1 \text { if respondent has ever been } \\
\text { unemployed, }=0 \text { otherwise. }\end{array}$ & 0.889 & 0.943 & 0.315 & 0.232 \\
\hline PROFESSOR & $\begin{array}{l}=1 \text { if respondent is a lecturer, }=0 \\
\text { otherwise. }\end{array}$ & 0.025 & 0.220 & 0.156 & 0.414 \\
\hline RANK & $\begin{array}{l}=1 \text { if researcher } \\
=2 \text { if lecturer } \\
=3 \text { if senior lecturer or professor }\end{array}$ & 0.574 & 1.307 & 0.707 & 0.744 \\
\hline RESEARCHER & $\begin{array}{l}=1 \text { if respondent is a researcher, }=0 \\
\text { otherwise. }\end{array}$ & .499 & .144 & .501 & .352 \\
\hline SCIENCE & $\begin{array}{l}=1 \text { if respondent works within the faculty } \\
\text { of science, }=0 \text { otherwise. }\end{array}$ & 0.166 & 0.294 & 0.373 & 0.456 \\
\hline $\begin{array}{l}\text { SENIOR LECTURER } \\
\text { OR READER }\end{array}$ & $\begin{array}{l}=1 \text { if respondent is a senior lecturer or } \\
\text { reader, }=0 \text { otherwise. }\end{array}$ & 0.102 & 0.257 & 0.303 & 0.438 \\
\hline SOCIAL SCIENCE & $\begin{array}{l}=1 \text { if respondent works within the faculty } \\
\text { of social science, }=0 \text { otherwise. }\end{array}$ & 0.164 & 0.167 & 0.371 & 0.373 \\
\hline ST ANDREWS & $\begin{array}{l}=1 \text { if respondent works in the university } \\
\text { of St. Andrews, }=0 \text { otherwise. }\end{array}$ & 0.183 & 0.175 & 0.388 & 0.380 \\
\hline TENURE & $\begin{array}{l}\text { Length of time with current employer, } \\
\text { measured in years. }\end{array}$ & 5.307 & 12.409 & 9.741 & 11.173 \\
\hline TENURE $^{2}$ & Tenure squared. & 122.703 & 278.599 & 768.287 & 452.036 \\
\hline $\begin{array}{l}\text { TIME OUT OF THE } \\
\text { LABOUR MARKET }\end{array}$ & $\begin{array}{l}\text { Time out of the labour force, measured in } \\
\text { months. }\end{array}$ & 1.231 & 0.131 & 3.227 & 0.645 \\
\hline
\end{tabular}




\section{IZA Discussion Papers}

No. Author(s)

51

A. Barrett

P. J. O'Connell

52 J. Mayer

R. T. Riphahn

53

J. Hartog

P. T. Pereira

J. A. C. Vieira

54 M. Lofstrom

55

L. Goerke

56

A. Lindbeck

D. J. Snower

57

I. N. Gang

K. F. Zimmermann

58

T. Bauer

K. F. Zimmermann

59

D. J. DeVoretz

S. A. Laryea

60

C. Belzil

J. Hansen

61

R. Winkelmann

62

A. Thalmaier

63

M. Ward

64

M. Ward

65

H. Lehmann

J. Wadsworth

A. Acquisti

66

E. J. Bird

H. Kayser

J. R. Frick

G. G. Wagner
Title

Area

Date

Does Training Generally Work?

5

$8 / 99$

The Returns to In-Company Training

Fertility Assimilation of Immigrants: Evidence

3

$8 / 99$

from Count Data Models

Inter-industry Wage Dispersion in Portugal: high

but falling

$8 / 99$

Labor Market Assimilation and the

$8 / 99$

Self-Employment Decision of Immigrant

Entrepreneurs

Value-added Tax versus Social Security

Contributions

Centralized Bargaining and Reorganized Work:

Are they compatible?

Is Child like Parent?

Educational Attainment and Ethnic Origin

9/99

Occupational Mobility of Ethnic Migrants

$9 / 99$

Canadian Immigration Experience:

Any Lessons for Europe?

Subjective Discount Rates, Intergenerational

Transfers and the Return to Schooling

Immigration: The New Zealand Experience

$10 / 99$

Bestimmungsgründe von Fehlzeiten: Welche

Rolle spielt die Arbeitslosigkeit?

1/2/3 9/99

6

$10 / 99$

Your Everyday, Average Academic

$10 / 99$

Salary and the Gender Salary Gap in the Academic Profession

Grime and Punishment: Job Insecurity and Wage 4

Arrears in the Russian Federation

$10 / 99$

The Immigrant Welfare Effect: Take-Up or

3

$10 / 99$ 

of Wage Differentials Transition Economies

\section{0 \\ J. C. van Ours}

J. Veenman
The Netherlands: Old Emigrants - Young Immigrant Country

Migration, Migrants and Policy in the United Kingdom

Privacy, time consistent optimal labor income taxation and education policy

Female Labour Supply, Flexibility of Working Hours, 1 and Job Mobility in the Netherlands

The Heterogeneity and Cyclical Sensitivity of 1 Unemployment: An Exploration of German Labor Market Flows 

Adversity

91 M. Lechner

Tenures that Shook the World: Worker Turnover in $\quad 4$ Russia, Poland and Britain

Identification and Estimation of Causal Effects of

An Evaluation of Public-Sector-Sponsored

Continuous Vocational Training Programs in East

N. Smith 
107 J. C. van Ours G. Ridder

J. Boone

J. C. van Ours

109 G. J. van den Berg

B. van der Klaauw

110 D. DeVoretz

C. Werner

111 V. Sorm

K. Terrell

L. Bellmann

T. Schank

113 R. Euwals

114 G. Brunello

A. Medio

115 A. Cigno

F. C. Rosati

116

C. Belzil

A. Haas

C. Klose

118 M. A. Shields

M. E. Ward

119 A. Lindbeck

D. J. Snower

120 P. T. Pereira

P. S. Martins

121 J. C. van Ours
Fast Track or Failure: A Study of the Completion

Rates of Graduate Students in Economics

Modeling Financial Incentives to Get Unemployed Back to Work

Combining Micro and Macro Unemployment

3

$1 / 00$

Duration Data

A Theory of Social Forces and Immigrant Second

1

$2 / 00$

Language Acquisition

Sectoral Restructuring and Labor Mobility:

A Comparative Look at the Czech Republic

Innovations, Wages and Demand for

5

$2 / 00$

Heterogeneous Labour: New Evidence from a

Matched Employer-Employee Data-Set

Do Mandatory Pensions Decrease Household

Savings? Evidence for the Netherlands

An Explanation of International Differences in

Education and Workplace Training

Why do Indian Children Work, and is it Bad for

3

$2 / 00$

Them?

Unemployment Insurance and Subsequent Job

3

$2 / 00$

Duration: Job Matching vs. Unobserved

Heterogeneity

IAB Employment Subsample 1975-1995.

Opportunities for Analysis Provided by the

Anonymised Subsample

Improving Nurse Retention in the British National

5

$2 / 00$

Health Service: The Impact of Job Satisfaction on Intentions to Quit

The Division of Labor and the Market for

Organizations

Does Education Reduce Wage Inequality?

5

Quantile Regressions Evidence from Fifteen

European Countries

Do Active Labor Market Policies Help Unemployed Workers to Find and Keep Regular Jobs? 
Rational Poverty or Poor Rationality? The Take-up of Social Assistance Benefits

125 F. Büchel

The Income Portfolio of Immigrants in Germany -

Effects of Ethnic Origin and Assimilation. Or:

J. R. Frick

126 J. Fersterer

R. Winter-Ebmer

Who Gains from Income Re-Distribution?

127 M. Karanassou

D. J. Snower

Smoking, Discount Rates, and Returns to

Education

Characteristics of Unemployment Dynamics: The

Chain Reaction Approach

128 O. Ashenfelter

D. Ashmore

O. Deschênes

Do Unemployment Insurance Recipients Actively

Seek Work? Evidence From Randomized Trials in

Four U.S. States

129 B. R. Chiswick

M. E. Hurst

C. Lucifora

The Employment, Unemployment and Unemployment Compensation Benefits of Immigrants

The Returns to Education in Italy: A New Look at the Evidence

Are Immigrants Favorably Self-Selected? An

134 A. D. Kugler

G. Saint-Paul

135 A. Barrett P. J. O'Connell

136 M. Bräuninger M. Pannenberg

Is There a Wage Premium for Returning Irish

Unemployment and Productivity Growth: An

Empirical Analysis within the Augmented Solow 
141 R. Hujer

M. Wellner

142

J. J. Dolado

F. Felgueroso

J. F. Jimeno

143 P. J. Luke

M. E. Schaffer

144 G. Saint-Paul

145 M.-S. Yun

146 T. K. Bauer

J. P. Haisken-DeNew

147 M. Belot

J. C. van Ours

148 L. Goerke

149 R. Lalive

J. C. van Ours

J. Zweimüller

150 J. DiNardo

K. F. Hallock

J.-St. Pischke

151 M. Ward
The Effects of Public Sector Sponsored Training on

Individual Employment Performance in East

Germany

Explaining Youth Labor Market Problems in Spain: 3

Crowding-Out, Institutions, or Technology Shifts?

Wage Determination in Russia: An Econometric 4

Investigation

Flexibility vs. Rigidity: Does Spain have the worst of 1 both Worlds?

Decomposition Analysis for a Binary Choice Model 7

Employer Learning and the Returns to Schooling

Does the Recent Success of Some OECD

Countries in Lowering their Unemployment Rates

Lie in the Clever Design of their Labour Market

Reforms?

Employment Effects of Labour Taxation in an Efficiency Wage Model with Alternative Budget Constraints and Time Horizons

The Impact of Active Labor Market Programs and Benefit Entitlement Rules on the Duration of Unemployment

Unions and the Labor Market for Managers

Gender, Salary and Promotion in the Academic Profession
5

$4 / 00$

3

$4 / 00$

7

$5 / 00$

$4 / 00$

$4 / 00$

$4 / 00$

$4 / 00$

$5 / 00$

$5 / 00$

$3 / 6$

$5 / 00$

An updated list of IZA Discussion Papers is available on the center's homepage www.iza.org. 